\title{
Manajemen Discharge Planning pada Klien dengan Demam Berdarah Dengue (DBD)
}

\author{
Fransisca Putry Novitasari ${ }^{1}$, Maria Dyah $\mathrm{K}^{2}$, David Nakka Gasong ${ }^{3}$, \\ Arwyn Weynand Nusawakan ${ }^{4}$ \\ Fakultas Kedokteran dan Ilmu Kesehatan, Universitas Kristen Satya Wacana, Indonesia \\ Email: arwyn.nusawakan@uksw.edu
}

\begin{abstract}
Management Discharge Planning For Clients With Dengue Hemorrhagic Fever (DHF). The role of nurses is very important, in discharge planning. Discharge planning is performed in all diseases to e the clients of the illness as well as the recovery of the patient after discharge from the hospital. One of them are patients with Dengue Hemorrhagic Fever (DHF). Discharge planning for DHF patient can be done by providing health education. Some studies find that discharge planning is in intermediate achievement because some factors such as formal education and age that affect maturity in thinking and acting. The purpose of this study is to describe the ability of nurses to perform discharge planning to a patient with DHF. This is qualitative research, the population in this study is nurses who are assigned to care DHF patient in Ambarawa Hospital. Data collected by semi-structured interview and validated by member check method. The results showed that discharge planning applied in Ambarawa Hospital was absolute discharge, and also discharge planning to DHF clients in Ambarawa Hospital was not effective yet because nurses did not know the number of dengue cases that should be reported in whole to the Health District Office. It is because the standard of success applying discharge planning depends on the reporting of DHF cases as a whole. To be concluded, delivering education must pay attention to three important aspects namely structure, culture, and technology.
\end{abstract}

Keywords: Absolute discharge, Dengue Hemorrhagic Fever, Discharge planning, Education

\begin{abstract}
Abstrak: Manajemen Discharge Planning pada Klien dengan Demam Berdarah Dengue (DBD). Peran perawat sangat penting dalam discharge planning. Discharge planning dilakukan pada semua penyakit dengan tujuan untuk kesembuhan klien dari penyakit serta pemulihan pasien paska pulang dari rumah sakit. Salah satunya pada pasien dengan penyakit Demam Berdarah Dengue (DBD). Discharge planning yang dilakukan pada klien dengan DBD dapat dilakukan dengan memberi edukasi. Beberapa hasil penelitian sebelumnya menunjukan faktor pendidikan formal dan usia mempengaruhi kematangan dalam berfikir dan bertindak dalam melakukan discharge planning. Tujuan penelitian ini adalah mengetahui fungsi management terkait discharge planning pada klien dengan DBD. Penelitian ini adalah penelitian kualitatif, partisipan dalam penelitian ini adalah perawat di RSUD Ambarawa yang merawat pasien DBD. Pengambilan data dilakukan dengan cara wawancara mendalam pada perawat yang merawat pasien DBD. Uji keabsahan data yang digunakan adalah member check. Hasil penelitian menunjukan bahwa discharge planning yang diterapkan di RSUD Ambarawa adalah absolute discharge, selain itu discharge planning pada klien DBD di RSUD Ambarawa belum efektif dikarenakan perawat belum mengetahui jumlah kasus DBD dilaporakan secara keseluruhan atau tidak ke Dinas Kesehatan. Hal ini dikarenakan tolak ukur keberhasilan discharge planning adalah pelaporan kasus DBD secara keseluruhan. Dapat disimpulkan, pemberian pendidikan harus memperhatikan tiga aspek penting yaitu struktur, budaya, dan teknologi.
\end{abstract}

Kata kunci: Absolute discharge, Demam Berdarah Dengue, Discharge planning, Edukasi

\section{PENDAHULUAN}

Demam Berdarah Dengue (DBD) adalah penyakit akut yang diakibatkan oleh infeksi virus dengue. Penularan virus dengue itu melalui gigitan nyamuk aedes albopictus, aedes polynesiensis dan aedes aegypti (Wowor, 2017).
Penularan juga bisa terjadi melalui perkawinan antara nyamuk jantan dan nyamuk betina serta penularan transovarial dari induk nyamuk ke keturunannya. Dari beberapa penularan virus dengue yang paling sering yaitu penularan melalui gigitan aedes aegypti. Virus dengue yang sudah masuk kedalam tubuh nyamuk akan 
berkembang biak selama 8 sampai 10 hari sebelum ditularkan ke manusia. Waktu yang dibutuhkan virus untuk berkembang tergantung suhu lingkungan. Nyamuk aedes aegypti biasanya mengigit dan menghisap darah pada siang hari.Puncak aktifitas tersebut mulai dari pukul 09.00 sampai 10.00 dan 16.00 sampai 17.00. Biasanya tempat yang mempunyai kemungkinan besar terjadinya penularan virus dengue yaitu di daerah endemis, pemukiman padat penduduk, kawasan industri, rumah sakit, pasar dan sekolah. Sekolah mempunyai peluang besar terjadinya penularan dikarenakan murid yang berasal dari berbagai wilayah tempat tinggal dan kemungkinan membawa jenis virus dengue yang berbeda.

Menurut World Health Organization (WHO), Demam Berdarah Dengue (DBD) sering ditemukan di daerah tropis dan subtropis. Data World Health Organization (WHO) menunjukan bahwa Asia menempati urutan pertama dari jumlah penderita Demam Berdarah Dengue (DBD) tiap tahunnya (WHO, 2012).

Pada konteks Asia Tenggara, Indonesia menempati urutan ke dua setelah Thailand terkait tingginya angka penyakit DBD (PUSDATIN, 2013). Hal ini dikarenakan Indonesia terletak di daerah tropis dan rentan terhadap perubahan iklim. Perubahan iklim akan mempengaruhi perkembangan atau mempercepat pertumbuhan nyamuk aedes aegypti sehingga siklus hidupnya menjadi lebih singkat. Di Indonesia Demam Berdarah Dengue (DBD) telah menjadi masalah kesehatan baik di wilayah perkotaan maupun wilayah semi-perkotaan. Perilaku vektor ada hubungannya dengan lingkungan dan dapat mempengarui terjadinya wabah Demam berdarah dengue (DBD) di daerah perkotaan. Penyebaran dengue dapat dipengaruhi oleh faktor iklim seperti curah hujan, kelembapan, dan suhu. Pada musim hujan kelangsungan hidup nyamuk akan lebih lama karena tingkat kelembapan tinggi (Nazri dkk, 2013).

Menurut data Kementrian Kesehatan (2013), menunjukan bahwa Indonesia menjadi endemis Demam Berdarah Dengue (DBD) sejak tahun 1968 sampai 2013, menyebar di 33 provinsi dan di 436 kabupaten atau kota dari keseluruhan kabupaten atau kota yang berjumlah 497. Untuk angka kesakitan atau incidence rate (IR) DBD dari tahun 1968 terus meningkat, menurun pada tahun 2010-2011 dan meningkat pada tahun 2012-2013 (41,25 per 100.000 penduduk).

Menurut Dinas Kesehatan Provinsi Jawa Tengah (2015), pada tahun 2014 angka kesakitan demam berdarah dengue sebesar 36,2/100.000 penduduk dan pada tahun 2015 cenderung meningkat menjadi 45,53/100.000 penduduk. Sedangkan angka kematian kasus DBD di Kabupaten Semarang tahun 2014 sebanyak 0,6\% (2 kasus). Data menunjukkan bahwa terjadi penurunan dibandingkan tahun 2013 yang tercatat sebanyak $1,01 \%$ (3 kasus). Data yang diperoleh dari rekam medis, tahun 2017 kasus DBD di Rumah Sakit Umum Daerah Ambarawa tercatat 75 penderita dan tidak ada pasien yang meninggal.

Gejala penyakit DBD yaitu demam dengan suhu $38^{\circ} \mathrm{C}$ sampai $39^{\circ} \mathrm{C}$. Apabila demam lebih dari 3 hari perlu dilakukan uji torniket, pemeriksaan IgM, IgG, IgM dengue. Pemeriksaan IgG biasa dilakukan setelah melewati hari ke-3, sedangkan pemeriksaan NS-1 diperiksa pada hari pertama atau ke-3 yang bertujuan untuk mendeteksi virus dengue lebih awal (Rafif, 2018). Selain itu dilakukan pemeriksaan cek darah rutin yang meliputi hemoglobin, hematokrit, leukosit dan trombosit. Tes tersebut harus dilakukan sampai penderita melewati fase kritis, yaitu fase yang terjadi setelah 5 hari menjalani fase demam dan merupakan fase yang paling sering terjadi kecolongan sehingga dapat menyebabkan keparahan bahkan meninggal (Rafif, 2018).

Management perawatan penanganan pada penyakit DBD dapat dilakukan dengan menganjurkan untuk tirah baring, makan makanan lunak, mengonsumsi air dan meningkatkan jumlah trombosit dalam tubuh yang kurang dari batas normal. Pada anak-anak nilai normal trombosit: $150-400 \mathrm{Mel} / \mathrm{Darah}$, pada orang dewasa: 200.000-400.000Mel/Darah (PERMENKES, 2014). Penanganan tidak hanya dilakukan ketika pasien di rawat di RS, namun perlu dilakukan discharge planning untuk mempersiapkan kepulangan pasien, dengan mengkaji kemungkinan perawatan lanjut dirumah sesuai kebutuhan atau rujukan ke tempat pelayanan kesehatan terdekat.

Discharge planning merupakan suatu proses dimana pasien mendapatkan pelayanan dari awal masuk rumah sakit hingga pulang ke rumah. Discharge planning dapat mengurangi lamanya perawatan pasien, meningkatkan kesehatan pasien, mencegah kekambuhan, menurunkan angka mortalitas dan morbiditas. Dalam proses keperawatan, discharge planning merupakan salah satu dari intervensi keperawatan. Intervensi yang dilakukan pada discharge planning yaitu perencanaan pulang, memberikan edukasi mengenai pola makan, pola istrihat dan kontrol setelah pasien pulang dari rumah sakit. Pelaksanaan discharge planning 
yang baik akan berpengaruh dengan peningkatan kualitas kesehatan pasien. Menurut Nursalam (2007) mengatakan bahwa dalam proses pelaksanaan discharge planning memiliki beberapa prinsip yaitu proses pelaksanaan discharge planning fokus terdadap pasien seperti kebutuhan, dan keinginan pasien harus dikaji secara berkala dari mulai masuk sampai keluar dari rumah sakit, mengidentifikasi masalah yang mungkin akan nampak setelah pasien pulang dari rumah sakit sehingga dapat mengetahui sejak dini masalah yang timbul, discharge planning dilakukan dengan melibatkan beberapa tim kesehatan seperti perawat, dokter, ahli gizi, discharge planning dilaksanakan di setiap tim kesehatan dimana dari pasien masuk maka discharge planning harus direncanakan dan dilakukan sesuai prosedur yang di terapkan di rumah sakit. Keberhasilan setelah dilakukan discharge planning, pasien dapat mengetahui dan memahami tentang masalah kesehatan yang diderita, pengobatan ketika pulang, perawatan lanjutan juka terjadi kegawatdaruratan, pengetahuan khusus kepada pasien dan keluarga untuk memastikan perawatan yang sesuai ketika pasien sudah pulang dari rumah sakit. Berkoordinasi dengan tempat pelayanan kesehatan terdekat unuk memantau status kesehatan pasien.

Melihat banyaknya jumlah kasus penyakit Demam Berdarah Dengue (DBD) di Rumah Sakit Umum Daerah Ambarawa, pihak rumah sakit menerapkan program discharge planning untuk mengurangi resiko penyakit baru. Dalam hal ini perawat berperan penting dalam melakukan discharge planning pada penyakit DBD. Program ini baru dimulai pada bulan Juli 2016 di Rumah Sakit Umum Daerah Ambarawa dan terlihat bahwa jumlah kasus DBD mengalami penurunan dari tahun 2016 sampai tahun 2017. Pada tahun 2016 terdapat 126 penderita dan 2 pasien yang meninggal kemudian pada tahun 2017 tercatat 75 penderita dan tidak ada pasien yang meninggal.

Pada penyakit Demam Berdarah Dengue (DBD), discharge planning tidak hanya diterapkan pada masalah klien saat sakit tetapi juga dari segi lingkungan dan pola hidup di rumah (Purnamasari, L. D., \& Ropyanto, C. B., 2012). Pelaksanaan discharge planning tidak lepas dari tanggungjawab perawat, dalam hal ini perawat mempunyai peranan penting dalam perencanaan pulang pasien. Pada pelaksanaannya perawat perlu berkomunikasi dengan baik serta terarah sehingga yang di sampaikan dapat di mengerti oleh pasien maupun keluarga untuk proses perawatan dirumah. Form discharge planning yang akan diberikan pada klien harus terdapat beberapa unsur, yaitu perawatan lanjutan di rumah, jenis obat yang harus di minum, cara perawatan diri yang dilakukan di rumah dan waktu pengobatan atau perawatan selanjutnya dilakukan.

Selain memberikan form discharge planning pada klien, peran perawat juga memberi edukasi. Edukasi yang dimaksud terkait dengan perawatan selama proses pemulihan penyakit seperti istirahat yang cukup pasca perawatan, konsumsi air putih 2000-2500cc/hari, makan makanan yang lunak, menghindari makan makanan yang terlalu asam dan pedas, melakukan 3M plus (menguras, menutup dan memanfaatkan kembali atau daur ulang), menggunakan kelambu dikamar tidur bila diperlukan, apabila suhu tubuh tinggi sampai tiga hari langsung berobat, minum obat sesuai aturan serta kontrol sesuai jadwal atau satu minggu setelah pulang dari rumah sakit. Penelitian yang dilakukan oleh Nursalam dan Ariyanto (2013) Pada proses pelaksanaan discharge planning di rumah sakit Borromeus Bandung, sebagian perawat $(58,1 \%)$ dari total 160 perawat berada dalam kategori cukup. Hal ini dipengaruhi oleh faktor pendidikan formal dan usia yang mempengaruhi kematangan dalam berfikir dan bertindak. Dari hasil penelitian tersebut dapat dilihat bahwa belum seluruhnya perawat mendukung pelaksanaan discharge planning.

Melihat banyaknya jumlah kasus Demam Berdarah Dengue (DBD) yang terjadi maka keberhasilan terkait menurunkan angka kejadian DBD juga terpengaruh dari keberhasilan discharge planning. Penelitian ini ingin melihat tentang sejauh mana management discharge planning pada klien dengan Demam Berdarah Dengue (DBD) di aplikasikan pada pasien yang dirawat di RSUD Ambarawa.

\section{METODE}

Metode penelitian ini menggunakan pendekatan kualitatif. Dimana informasi diperoleh dengan menggunakan alat ukur berupa data-data dari hasil wawancara mendalam ataupun informasi yang berupa cerita dari partisipan. Berdasarkan perolehan informasi di atas penulis dapat memperoleh informasi lebih banyak dan detail sebagai salah satu sumber untuk menarik simpulan. Partisipan dalam penelitian ini adalah perawat di ruang anggrek RSUD Ambarawa. Dalam penelitian ini jenis data yang dikumpulkan ada dua jenis yaitu data primer dan data sekunder. Data primer adalah data yang dikumpulkan, diolah sendiri oleh 
peneliti langsung dari responden. Data sekunder merupakan data yang diperoleh dalam bentuk yang sudah jadi, yang diperoleh dari sumber dokumenter yang ada di RSUD Ambarawa, khususnya data yang berhubungan dengan penelitian, yang meliputi data tentang kasus penyakit DBD.

Lokasi penelitian ini di Rumah Sakit Umum Daerah Ambarawa, diruang anggrek. Metode yang dilakukan pada penelitian ini adalah dengan wawancara mendalam. Lamanya partisipan di wawancarai kurang lebih 2 minggu dengan frekuensi 3 kali. Jumlah partisipan dalam penelitian ini sebanyak 2 orang dengan kriteria perawat yang merawat kasus DBD di RSUD Ambarawa.

Teknik analisa data menggunakan analisa data deskripsi isi konten analisis data primer atau hasil wawancara mendalam. Tahap analisa data yang dilakukan pada penelitian kualitatif yaitu: reduksi data atau penambahan data yang dirasa data tersebut penting sebagai bahan informasi. Kedua, proses pengumpulan informasi akan di analisa dengan metode analisis konten. Tahap terakhir yaitu, penarikan kesimpulan. Uji keabsahan data dilakukan dengan metode member check untuk melakukan konfirmasi data.

Penelitian ini telah mendapatkan persetujuan etik penelitian (ecthical approval) dari Komite Etik Penelitian Kesehatan Fakultas Kedokteran dan Ilmu Kesehatan Universitas Kristen Satya Wacana Nomor 082/PE/KEPK.UKSW/2018.

\section{HASIL}

Penelitian ini bertujuan untuk menggambarkan management discharge planning pada klien Demam Berdarah Dengue (DBD) yang dilakukan di Rumah Sakit Umum Daerah (RSUD) Kecamatan Ambarawa. Penelitian yang dilakukan pada bulan April sampai Juli 2018 ini telah melibatkan dua Riset partisipan yaitu perawat pelaksana yang sehariharinya telah melakukan discharge planning sesuai dengan kriteria yang telah tercantum pada metode penelitian.

RSUD Ambarawa merupakan rumah sakit Pemerintah Daerah yang berada di Jalan Kartini No. 101 Ambarawa Kab. Semarang dengan luas $12.000 \mathrm{~m}^{2}$. Rumah sakit ini berdiri pada tahun 1930 sebelum Indonesia merdeka. RSUD Ambarawa pada mulanya dimiliki oleh Yayasan Khatolik pada masa Pemerintahan Hindia Belanda. Pengelolaan rumah sakit sebagian di serahkan kepada Pemerintah Kabupaten Tingkat
II pada tahun 1945, namun pada tahun 1956 pengelolaan secara penuh diserahkan kepada Pemerintah Kabupaten Tingkat II Semarang.

RSUD Ambarawa menjuarai dalam lomba Citra Pelayanan Prima Tingkat Kabupaten Semarang. Terlihat bahwa dalam memberikan pelayanan berjalan dengan lancar sehingga mendapat kepercayaan berbagai pihak dari waktu ke waktu. Pada tanggal 10 November 2014, RSUD Ambarawa mendapatkan akreditasi ISO 9001 pada tahun 2008 untuk rekam medis, Instalasi Gawat Darurat (IGD), layanan rawat jalan termasuk perinatologi dan ginekologi, laboratorium, farmasi, radiologi, Intensive Care Unit (ICU), Instalasi Bedah Sentral (IBS), Instasi Gizi, dan proses pendukung. Selain itu, RSUD Ambarawa berkomitmen memberikan pelayanan yang sempurna dan paripurna kepada pelanggan, sehingga dari waktu ke waktu berbagai pihak memberikan kepercayaan kepada RSUD Ambarawa. Hal tersebut tidak lepas dari visi RSUD Ambarawa yaitu "Menjadi Rumah Sakit yang berkualitas, terpercaya, dan kebanggaan masyarakat".

Salah satu layanan yang diberikan kepada pasien adalah program discharge planning. Menurut hasil penelitin program discharge planning di RSUD Ambarawa sudah dilakukan sesuai dengan Standar Operasional Prosedur (SOP). Kesesuaian ini dapat terlihat bahwa program discharge planning sudah berjalan dengan baik khusunya pada klien DBD. Program discharge planning pada pasien DBD menjadi salah satu upaya RS untuk menekan jumlah penderita DBD. Berdasarkan data dari rekam medis, jumlah kasus DBD mengalami penurunan sejak diterapkannya program discharge planning.

Pada penelitian ini, peneliti berhasil menjawab tujuan penelitian yang akan disajikan dalam 2 tema dari hasil wawancara mendalam dengan partisipan yaitu: 1) RS sudah melakukan discharge planning dengan absolute discharge. 2) Pelaksanaan discharge planning sesuai SOP. Masing-masing tema yang didapatkan dari wawancara dengan partisipan akan diuraikan sebagai berikut:

\section{Pelaksanaan Discharge Planning dengan Absolute Discharge}

Program discharge planning bertujuan untuk mengurangi angka kekambuhan penyakit pasien, hal tersebut juga yang diupayakan oleh program discharge planning di RSUD Ambarawa pada kasus Demam Berdarah Dengue (DBD). Terlebih khusus, discharge planning yang dilakukan adalah jenis absolute discharge atau 
pulang mutlak. Ini merupakan akhir dari hubungan pasien dengan RS tetapi apabila pasien perlu di rawat kembali maka prosedur perawatan dapat dilakukan lagi.

Keputusan pasien sudah diperbolehkan pulang dan mendapatkan discharge planning diputuskan oleh dokter. Selanjutnya yang terlibat dalam pelaksanaan discharge planning adalah keluarga yang memberikan dukungan atau support supaya cepat sembuh dan membantu dalam perawatan di rumah, perawat yang memberikan pendidikan kesehatan kepada pasien dan keluarga untuk mempersiapkan pemulangan dan kebutuhan untuk perawatan tindakan lanjut di rumah, dokter memberikan terapi pengobatan selama perawatan di rumah dan ahli gizi memberikan pendidikan kesehatan tentang gizi makanan yang konsumsi selama perawatan di rumah. Namun yang paling dominan adalah dokter karena dokter yang menentukan diagnosa penyakit dan dalam pemberian obat, sedangkan perawat sebagai pelaksana.

\section{Gambaran Discharge Planning}

Gambaran pelaksanaan discharge planning di ruang anggrek diantaranya pemberian edukasi kepada pasien dan keluarga pasien. Edukasi yang diberikan meliputi (cara menjaga lingkungan sekitar, pola makan pasien, pemberian obat dan mengenai kontrol pada pasien). Dalam melakukan discharge planning perawat berkolaborasi bersama dokter, ahli gizi dan keluarga.

Pelaksanaan discharge planning di ruang anggrek di dukung oleh SDM yang baik, yaitu terdapat 44 bed dan perawat di ruang anggrek sebanyak 21 orang. Untuk fasilitas program discharge planning terdapat beberapa komponen yaitu alat yang dibutuhkan keluarga untuk pasien, cara penggunaan peralatan yang diperlukan pasien, memberi edukasi kepada pasien dan keluarga pasien mengenai pola makan pasien serta obat-obatan dipastikan selalu tersedia di rumah.

Setelah pasien pulang dari RS selanjutnya evaluasi dilakukan seminggu setelah pasien di rumah. Evaluasi yang dilakukan dapat melalui telepon, kuesioner maupun kunjungan rumah (home visit). Hasil dari evaluasi tersebut akan dilaporkan ke Dinas Kesehatan dan selanjutnya Dinas Kesehatan menindaklanjuti kasus penyakit tersebut.

\section{PEMBAHASAN \\ RS Sudah Melakukan Discharge Planning dengan Absolute Discharge}

Penerapan absolute discharge (pulang mutlak atau selamanya) ini baik karena secara kondisi memungkin pasien untuk pulang. Sejalan dengan penelitian yang dilakukan Suprapti, Nur, \& Madya (2013), pasien dikatakan siap untuk pulang bila pasien dan keluarga dapat melakukan perawatan di rumah secara mandiri. Kesiapan adalah kondisi secara keseluruhan yang dapat membuat seseorang mampu menghadapi situasi dengan cara menyesuaikan diri. Dalam hal ini, perawat mempunyai peranan yang penting dalam perencanaan pulang, dalam berkomunikasi harus terarah agar hal yang sudah di sampaikan dapat di mengerti pasien maupun keluarga pasien untuk perawatan di rumah. Penelitian yang dilakukan oleh Siahaan (2010), sebelum dilakukan discharge planning, pasien sudah mempunyai motivasi yang tinggi untuk sembuh. Dalam hal ini perawat harus berkomunikasi dengan pasien maupun keluarga pasien secara jelas agar mereka dapat mengerti untuk perawatan di rumah. Discharge planning yang kurang tepat juga bisa berdampak kepada pasien yang kembali lagi ke rumah sakit pasca perawatan dan akhirnya pasien menanggung biaya rawat inap serta obat selama di rumah sakit. Pasien yang memerlukan perawatan di rumah atau penyuluhan kesehatan, dan pelayanan komunitas tetapi tidak dibantu oleh petugas rumah sakit terkhususnya perawat di rumah sakit, pada saat sebelum pemulangan pasien akan berakibat pasien kembali lagi kerumah sakit untuk dirawat. Menurut Rofi' $i, M$. (2011) mengatakan ada beberapa faktor yang bisa mempengaruhi discharge planning yaitu komunikasi, keterlibatan keluarga dan pasien, dan faktor personil discharge planning.

Dapat ditarik kesimpulan pasien siap pulang apabila mampu melakukan perawatan lanjutan secara mandiri.

\section{Gambaran Discharge Planning}

Dalam discharge planning, salah satu peran perawat yaitu sebagai planner yang bertugas untuk menentukan tujuan bersama pasien dan keluarga, mengevaluasi kesinambungan asuhan keperawatan, memulihkan kembali kondisi pasien secara optimal, mengkaji setiap pasien dengan mengumpulkan informasi atau data yang berhubungan untuk mengidentifikasi masalah aktual dan potensial. Edukasi yang diberikan kepada pasien maupun keluarga pasien perlu 
direncanakan secara matang karena pemantapan materi mempengaruhi tingkat keberhasilan program discharge planning. Pelaksanaan discharge planning telah direncanakan sebelumnya atau program sehingga tidak terkesan tergesa-gesa yang memungkinkan pasien dan keluarga pasien dapat menerima informasi tersebut dengan jelas. Pelaksanaan discharge planning sebaiknya dilaksanakan sejak pasien datang di rumah sakit sampai pasien akan pulang sebab akan lebih efisien dalam mempersiapkan pasien dalam perawatan mandiri di rumah. Pasien dan keluarga memahami dan dapat mendiskusikan kembali apabila ada yang kurang jelas. Di dukung oleh penelitian yang dilakukan Devi Darliana bahwa diharapkan perawat melaksanakan seluruh proses discharge planning dari pengkajian sampai evaluasi. Namun pada penelitian Herniyatun, Nurlaila dan Sundari (2009) mengatakan bahwa dalam pemberian edukasi mengenai discharge planning yang kurang optimal yang dilakukan perawat dapat berakibat pasien kurang memahami ataun mengerti apa yang harus dilakukan, sehingga perawatan lanjutan pasien dapat terhambat.

Perawat diharapkan untuk meningkatkan ketrampilan dan pengetahuan discharge planning dengan mengikuti pelatihan-pelatihan, seminar maupun workshop agar dapat mengaplikasikan kepada pasien. Namun belum tentu juga discharge planning kurang optimal yang diberikan perawat tetapi tingkat pemahaman pasien juga mempengaruhi. Menurut Lestari, E. D. W. I. (2010), pasien yang bisa menangkap informasi dengan baik dapat melakukan penatalaksanaan terhadap penyakitnya. Sebaliknya pasien atau keluarga yang tingkat pemahamannya kurang, hal tersebut belum tentu menjadi faktor dalam ketidakpatuhan melakukan penaktalaksanaan discharge planning. Evalusi discharge planning harus di koreksi dengan cermat agar menjamin kualitas pelayanan yang sesuai. Dari hasil penelitian yang mengatakan bahwa ada kunjungan ke rumah pasien untuk mengevaluasi discharge planning. Ini didukung dengan penelitian Wijayanti, A. E., \& Kusumawati, A. S. (2014). Yang mengatakan bahwa evaluasi lanjutan dilakukan setelah seminggu pemulangan dari rumah sakit, melalui kunjungan rumah atau home visit. Evaluasi dilakukan dengan harapan mendapatkan hasil yang optimal sesuai dengan tujuan dilakukannya discharge planning. Pada penelitian Dedi, B. (2013) mengatakan bahwa tahap evaluasi pada pelaksanaan discharge planning bukan hanya sekedar memberikan kesempatan kembali kepada pasien terhadap apa yang telah diberikan. Mendokumentasikan hasil kegiatan yang sudah dilakukan dalam bentuk catatan dalam pelayanan bagi pasien. Data yang lengkap dan kongkrit dapat memberikan informasi dalam menentukan keputusan. Baik dalam pengobatan, tindakan, dan penanganan medis. Surat kontrol yang diberikan kepada pasien untuk pemberitahuan kapan dan dimana pasien akan melakukan kontrol kembali kesehatannya.

Dapat ditarik kesimpulan, dalam memberikan edukasi kepada pasien maupun keluarga pasien harus disampaikan dengan tidak tergesa-gesa agar mereka dapat menerima informasi dengan jelas untuk menjamin terjadinya kontinuitas perawatan di rumah.

\section{SIMPULAN}

Pelaksanaan discharge planning di Rumah Sakit Umum Daerah Ambarawa, ruang anggrek didukung dengan fasilitas dan SDM yang memadai. Dalam pelaksanaan, discharge planning tidak lepas dari tim kesehatan seperti dokter, ahli gizi dan melibatkan keluarga dalam proses discharge planning. Penelitian ini masih membahas secara umum tentang discharge planning untuk itu perlu dilakukan penelitian lebih lanjut.

\section{DAFTAR PUSTAKA}

Devi Darliana. (2012). Discharge Planning Dalam Keperawatan. Idea Nursing Journal Vol.III No.2.

Dinas Kesehatan Jawa Tengah. (2015). Profil Kesehatan Provinsi Jawa Tengah.

Herniyatun, Nurlaila., \& Sudaryani. (2009). Efektifitas program discharge planning terhadap tingkat kepuasan pasien di Rumah Sakit Umum Daerah
Kabupaten Kebumen Tahun 2009. Jurnal Ilmiah Kesehatan Keperawatan.

Lestari, E. D. W. I., Studi, P., \& Keperawatan, I. (2010). Hubungan tingkat pemahaman tentang discharge planning dengan kepatuhan pasien dalam penatalaksanaan diabetes. Naskah Publikasi, STIKES Aisyiyah Yogyakarta.

Nazri, C. ., Hashim, A., Rodziah, I., \& Hassan,
A.Y.
(2013)
Utilization 
geoinformationtools for dengue control managementstrategy: a case study in Seberang Prai, Penang Malaysia. International Journal of Remote Sensing Applications, 3(1), 11-17.

Nursalam, Ariyanto. (2013). Pedoman Penyelengaraan Pelayanan Keperawatan di Rumah Sakit. Jakarta: Direkorat Pelayanan.

Nursalam. (2007). Managemen keperawatan: Aplikasi dalam Praktek keperawatan profesional. Jakarta: Salemba Medika.

PERMENKES. (2014). Panduan praktik klinis bagi dokter di fasilitas pelayanan kesehatan primer.

https://peraturan.bkpm.go.id/jdih/userfiles/ batang/Permenkes_5_2014.pdf

Purnamasari, L. D., \& Ropyanto, C. B. (2012). Evaluasi Pelaksanaan Perencanaan Pulang. Jurnal Keperawatan Diponegoro, 1(1), 213-218.

PUSDATIN. (2013). Situasi demam berdarah dengue di indonesia. www.depkes.go.id/article/print/.../wilayahklb-dbd-ada-di-11-provinsi.html\%0A\%0A

Rafif, Naufal. (2018). Perbedaan Manifestasi Klinis Penyakit Pada Pasien Demam Berdarah Dengue Infeksi Primer Dan Sekunder. (Skripsi, Universitas Lampung).

Rofi'i, M. (2011). Analisis faktor-faktor yang mempengaruhi pelaksanaan perencanaan pulang pada perawat di Rumah Sakit Islam Sultan Agung Semarang. (Tesis, Universitas Indonesia).

Siahaan, M.S.U. (2010). Penatalaksanaan TB Paru Rumah Sakit Umum Daerah Sidikalang Tahun 2010. (Skripsi, Universitas Sumatera Utara). Medan

Suprapti, E., Nur, T., \& Madya, K. (2013). Pengaruh Discharge Planning Terstruktur Untuk Meningkatkan Kesiapan Pasien TB Paru Menghadapi Pemulangan (Studi Eksperimental di RSUD Tugurejo Dan RSUD Kota Semarang ). Jurnal Ilmu Keperawatan dan Kebidanan, 9(1).

WHO. (2012). Dengue and Severe Dengue. http://www.who.int/mediacentre/factsheets /fs117/en/

Wijayanti, A. E., \& Kusumawati, A. S. (2014). Gambaran Stres Mahasiswa Terhadap Prestasi Belajar Mahasiswa Keperawatan. Pelaksanaan Discharge Planning pada Pasien Post Sectio Caesaria. Jurnal Unisa Yogyakarta. http://digilib.unisayogya.ac.id/2344/1/4jur nal\%20JKK\%20desember14\%20OK.pdf\#page $=30$

Wowor, R. (2017). Pengaruh kesehatan lingkungan terhadap perubahan epidemiologi demam berdarah di Indonesia. Jurnal E-Clinic, 5(2). 